\title{
SIMPLE METHODS OF IDENTIFYING PULPWOODS
}

\author{
By J. D. Hale. \\ Forest Products Laboratories of Canada, Ottawa
}

$\mathrm{T}^{\mathrm{Ma}}$ HOSE who inspect considerable quantities of pulpwood realize that it is sometimes difficult to distinguish the different species.

Standing timber presents no difficulty to woodsmen because growing trees can be identified by ordinary visual examination. Logs with bark are identified almost as easily, especially when the logs are freshly sawn from the tree. If, however, the logs have been floated for any considerable time the bark may be entirely lost and with the loss of this useful identifying character, it is necessary to depend on the characters of the wood itself where identification is required. The bruised ends and darkened surface of logs that have travelled long distances and for a considerable time in water are factors which add to the difficulty of making "snap" identifications.

It is necessary that the wood-using industries have reliable methods of distinguishing the various woods, for however simple a matter it may be to distinguish different species of timber as forest trees or in log form, the characters which serve to distinguish sawn lumber of different species seem relatively less known, and on this account boards of one species may become mixed with those of another. Under such circumstances the necessity naturally arises for positive identification of the wood. It seems certain that as methods of wood identification become more widely known, the likelihood of undesirable admixtures will diminish.

Accurate methods of identification are as important in the case of pulpwood as for sawn lumber. One requirement of primary importance in commercial practise is that the method of distinguishing woods be as simple as is consistent with accuracy. It is an obvious advantage if the method of identification is so easy to apply as to enable a scaler to determine the species of logs as rapidly as they pass along the conveyor. The bruised ends and darkened surface of some water-driven pulpwood, however, tends sometimes to make such rapid identification difficult, if not impossible, but in the hope that some generally applicable method of "snap" identification may be devised or is possibly in use even now in some region, we will attempt to describe some of the features of use in identifying pulpwood material that have been employed by the Forest Products Laboratories. It is hoped that the practical men of the pulp and paper industry will criticize the suggestions and offer some of their own methods of identifying pulpwood so that all suggested systems may be tried on pulpwood of various localities with the end of discovering quick and easy means of identification that can be applied generally.

The important pulpwoods of eastern Canada are, of course, the spruces 
with balsam and jack pine varying in importance with the locality. In some regions such woods as hemlock and the tamarack or larch may very occasionally be found in pulpwood. The qualities of spruce have made its various species the most prized pulpwoods and since the manufacturers of high grade paper have generally attempted to set limits to the amount of wood other than spruce that they will accept in pulpwood, the importance that is attached to positive methods of identifying the pulpwood species is evident.

There are numerous characters useful for identifying woods. In the case of round logs, the bark is very helpful. Also the colours of the wood, the appearance of knots, the presence of resin and the general conformation of the annual wood layers constitute combinations of features which serve to identify the pulpwood species. All these characters are recognizable on visual inspection of freshly cut material. When, however, the inspector is confronted by pulpwood without the bark with a surface discoloured by a long sojourn in water and with the ends of the log so bruised that the general growth characters are utterly obscured, it may be very difficult to decide to what species it belongs. The only infallible method (or at least the only one known to the Forest Products Laboratories) for identifying pulpwood so disguised is to examine the structure of such material with a pocket magnifier, even though this procedure may appear to reverse the order in which problems of "snap" identification should be approached.

For examining the structure of a pulpwood bolt with low power pocket magnifier, it is necessary to make a clean cut on one end of the bolt (at a right angle to the main axis of the bolt, that is at right angles to the grain). On examination of this cleanly cut end grain surface the wood will be seen to have a layered structure. Each of these layers is the wood added in one year's growth, and because of their circular cross section such annual layers are called annual rings. In healthy trees the outside layers of wood are nearly white or cream colour, and in some woods are distinguished from darker coloured heartwood in the central portion of the log. The light coloured outer band of wood is known as sapwood, and may be composed of many years' growth-the thickness of sapwood depending in general on the age of the tree, the species, and the rate of growth. The wood of young trees is entirely sapwood. It is only after the tree has grown to have considerable diameter or has become fairly old that the heartwood is formed. Small pulpwood bolts that have grown very rapidly may consist entirely of the light coloured sapwood.

Now, in order to see the minute structure of the annual layers, it is neces. sary to make a clean cut with a very sharp knife. Such a surface will show under the magnifier of the ordinary ten times magnifying power a regular structure somewhat like a honeycomb. (See the illustrations, figures 1,2 


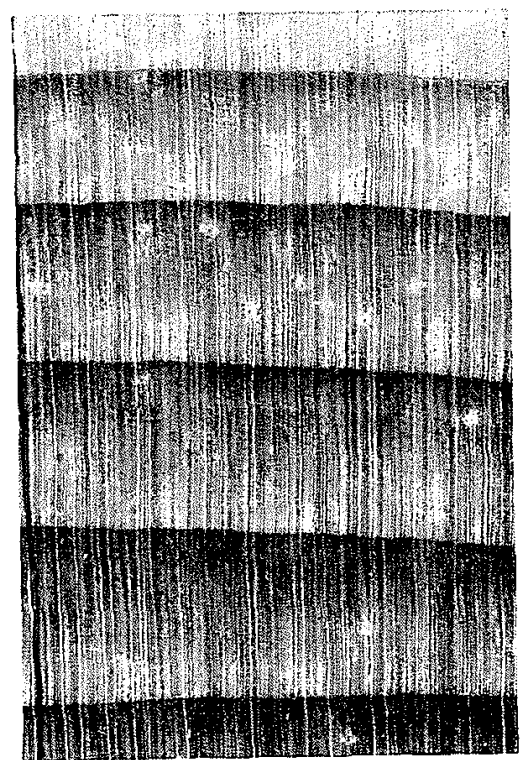

FIGURE 1

White spruce (Picea canadensis (Mill) B.S.P.) -End grain surface of wood. Magnified to indicate appearance under pocket magnifier. sote resin ducts which appear as whis is one-quarter inch.

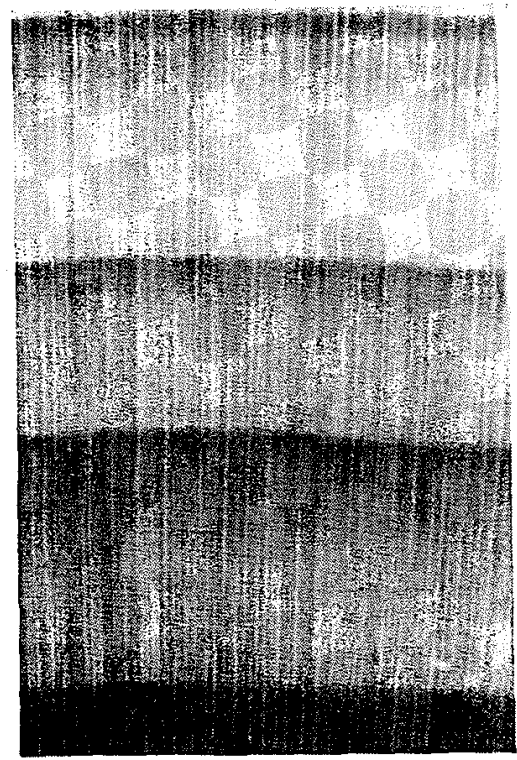

FIGURE 2

Balsam fir (Abies balsamea (L.) Miller). End grain surface of woot. Note absence of resill ducts. Same magnification as Fin. 1.

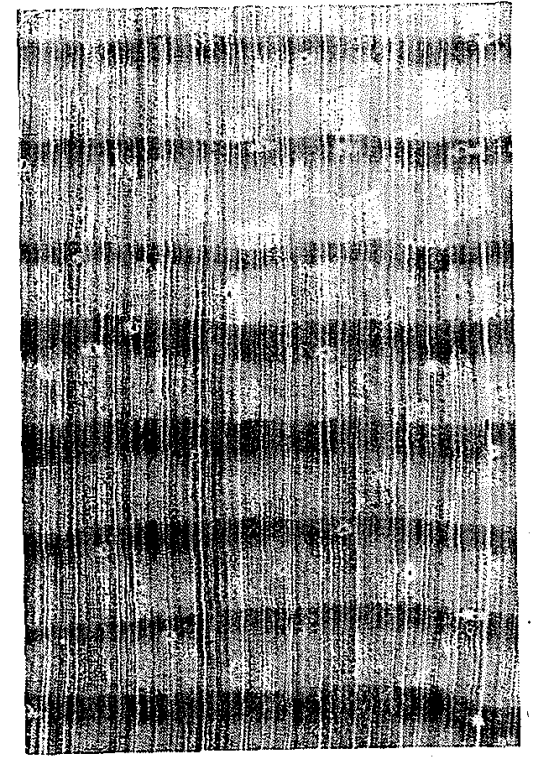

FIGURE 3

Jack Pine (Pinus banksiana Lam.) End grain surface of wood. Note the frequent large Sase magnification as Figure I.

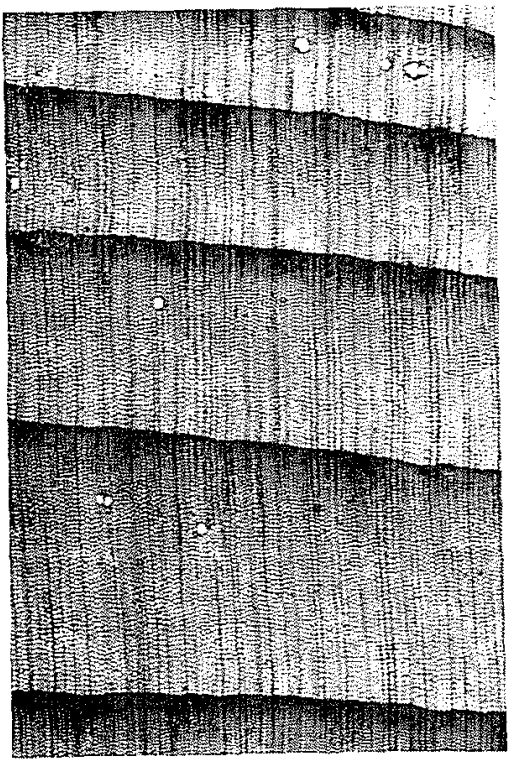

FIGURE 4

White spruce XI5-Transverse section 


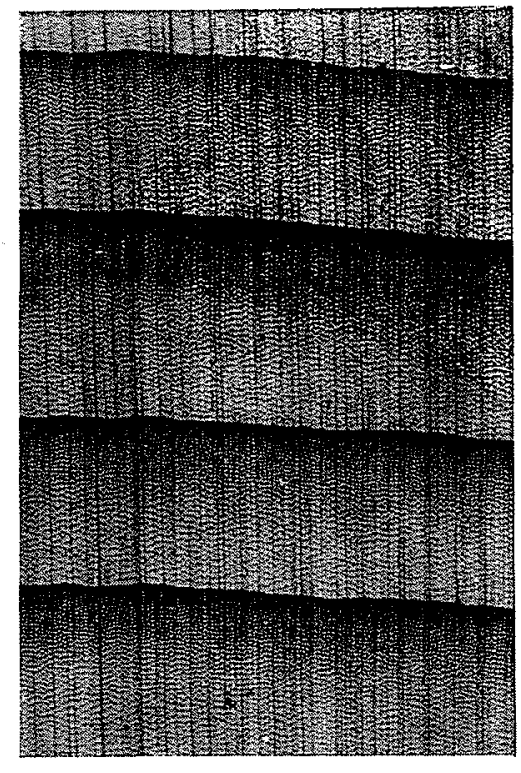

FIGURE 5

Balsam fir X15-Transverse section.

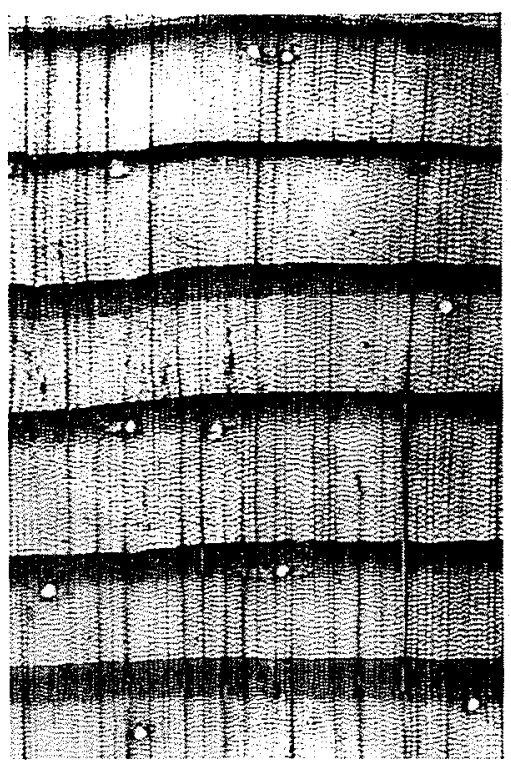

FIGURE 6

Jack pine X15--Transverse section

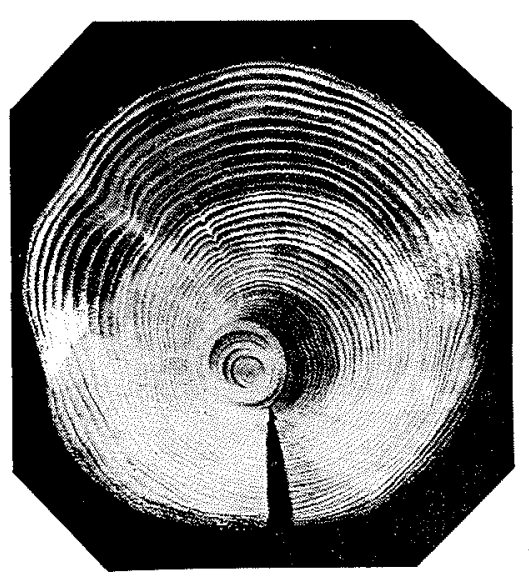

FIGURE 7

End of spruce bolt showing "compression" wood. 
and 3). The pulpwoods under discussion are composed largely of tiny tubular cells with closed and pointed endings. Packed close together as these cells are and arranged parallel to the log, a section cut across such tabular structures reveals their regular arrangement in radial rows (that is in series in a generally straight line from the centre of the tree to the bark).

Each annual layer in such a wood as jack pine, (see figure 3 ) is composed of a comparatively light and soft portion on the inside towards the centre of the log and a dark harder region at the outside towards the bark. The variation in hardness between the inner and outer part of the annual layer is noticeably due to the difference in cell structure of the two regions. The inner layer is composed of cells with relatively large cavities and thin walls, whereas the outer region is composed of cells with small cavities and thicker walls. As each successive year's growth of wood is deposited outside the preceding layer, the beginning of the growing period in spring produces the thin walled cells with large cavities which form the inner light layer known as springwood, subsequent growth producing the heavier walled cells with smaller cavities which compose the outer part of the annual layer called summerwood. The growing period ends with this hard layer upon which the next year's growth adds the new layer of springwood, so that the contrast in colour between light springwood and heavy summerwood distinguishes the separate annual increments sufficiently to give such timber its characteristic layered appear. ance.

Examination with the magnifier discloses in addition to the fibrous cells, numerous light fine lines which cross the annual layers in a radial direction. Such fine lines are the rays. Rays are minute ribbon-like structures in softwoods formed of short cells which are grouped into these radially extending strands which pass at right angles to the fibrous elements of the wood. Rays are present in softwoods and hardwoods and are called wood rays or some. times medullary rays.

In some of the softwoods there are also resin ducts or canals which appear on the end surface either as minute openings or as small light-coloured spots. These ducts extend vertically in the direction of the fibrous cells and are often visible, especially in pine, on planed longitudinal surfaces as dark streaks like longitudinal scratches. Resin ducts are sometimes open and empty in dry wood and sometimes closed either because full of resin or because the cavity in heartwood becomes filled with growth of small wood cells known as tyloses. Some resin canals extend radially but these are difficult to see with a small magnifier.

The presence or absence of typical resin canals and the character of the summerwood furnish a basis sufficient when colour, odour and weight of wood are considered, to identify with accuracy the chief Canadian pulpwoods 
with the aid of a sharp knife, by means of which smooth surfaces may be cut, and a pocket magnifier of about ten times magnifying power for close examination of these smoothly prepared surfaces.

Sometimes the colour and odour of pulpwood may be masked, and since only spruce, balsam, jack pine, tamarack and hemlock are being considered, these woods can be distinguished by structure alone. All of these softwoods may be identified with the aid of the magnifier in the manner described by observing the characters visible on end grain surfaces. Spruce and jack pine, for example, both have resin ducts, but the ducts of pine are noticeably larger, more distinct and numerous than the small scattered ones in spruce. Moreover, the transition from springwood to summerwood is rather abrupt in jack pine, which has comparatively broad summerwood, whereas the transition between springwood and summerwood in spruce is very gradual. In this connection the wood of the tamarack or larch should be mentioned since this species also shows a few scattered and small resin ducts which are usually more difficult to find than those in spruce. Larch would never be confused with jack pine, although its summerwood has a similar abrupt transition from the springwood and is as conspicuous as that of jack pine.

Balsam fir and hemlock are normally without resin ducts, but the two species are readily distinguished, because in balsam in the transition from springwood to summerwood is very gradual. The summerwood of balsam is so narrow and little developed that wood of this species is rather uniformly soft and easily cut, whereas the wood of hemlock has more summerwood and is harder than balsam. Although both of these woods are normally without resin ducts, these structures may sometimes occur in both balsam and hemlock as a result of wounds. In the abnormal cases where such traumatic resin ducts do occur they are in the neighborhood of the wound and are likely to be close together in little bands which follow the curvature of the annual rings.

In the regions where both black spruce and white spruce are cut, it is often difficult to distinguish these species by the wood. Black spruce is generally the smaller tree and usually has narrower growth rings than white spruce. Also, the summerwood of black spruce is typically much heavier than that of white spruce. The wood of red spruce is intermediate in summerwood content between the other two eastern spruces.

The characters mentioned here can usually be seen clearly on end grain surfaces. If the wood examined is very wet, it may be possible to cut a thin slice off the end and to examine this slice against the light. By this method the resin ducts are visible as tiny holes if sapwood is examined, or sometimes as opaque dots in the heartwood. Figures 4,5 , and 6 are photomicrographs of thin sections of spruce, balsam and jack pine. These were photographed by 
transmitted light and are included to show the structure accurately. Such sections are, of course, carefully sliced with a special machine and are very different from the crude slices removed by hand with a sharp knife for exam. ination of wet wood in the field. These figures show the actual structure rather better than figures 1,2 and 3, which are photographs of wood surfaces, although the latter are more like what is actually visible when the wood is examined by a pocket magnifier.

It is hardly necessary to employ the pocket magnifier for identifying freshly cut material since such logs are generally easy to identify. Balsam for example has typical smooth bark with raised "blisters" full of oleo-resin, a character which sets it apart from all other pulpwoods. It is also easy to distinguish typical characters of wood by mere visual inspection without the aid of any magnifier. In jack pine for instance the colour of the heart distinguishes it from spruce just as surely as characters of bark and knots. In view of the variety of characters, it seems advisable to tabulate methods that may be of especial use identifying pulpwood species under various conditions beginning with the standing timber in the forest.

The characters which distinguish standing timber are so very widely known that a brief summary of them will suffice. Some of the main identifying features are mentioned in the following description of the various woods.

CHARACTERS OF USE IN IDENTIFYING SOFTWOOD PULPWOOD SPECIES AS STANDING TIMBER AND IN FORM OF LOGS WITH BARK

Spruce (Picea).-Leaves scattered, short, needle like, four sided, and generally diamond shaped in cross section pointing every way. Cones maturing the first year becoming pendulous; scales thin, without thickenings or prickly tips. The cones do not disintegrate readily (a marked contrast to balsam in this respect).

There are three eastern species, white spruce, ( $P$. canadensis), black spruce ( $P$. mariana), and red spruce ( $P$. rubra). White and black spruce are widely distributed, but red spruce is limited in its Canadian range to the country east of the St. Lawrence. Some of the characters useful in distinguishing the three spruces as standing timber are herewith compared according to Morton (Forest Service Bulletin 61, Native Trees of Canada) from whose work much of the description of characters which distinguish the standing timbers is borrowed. 


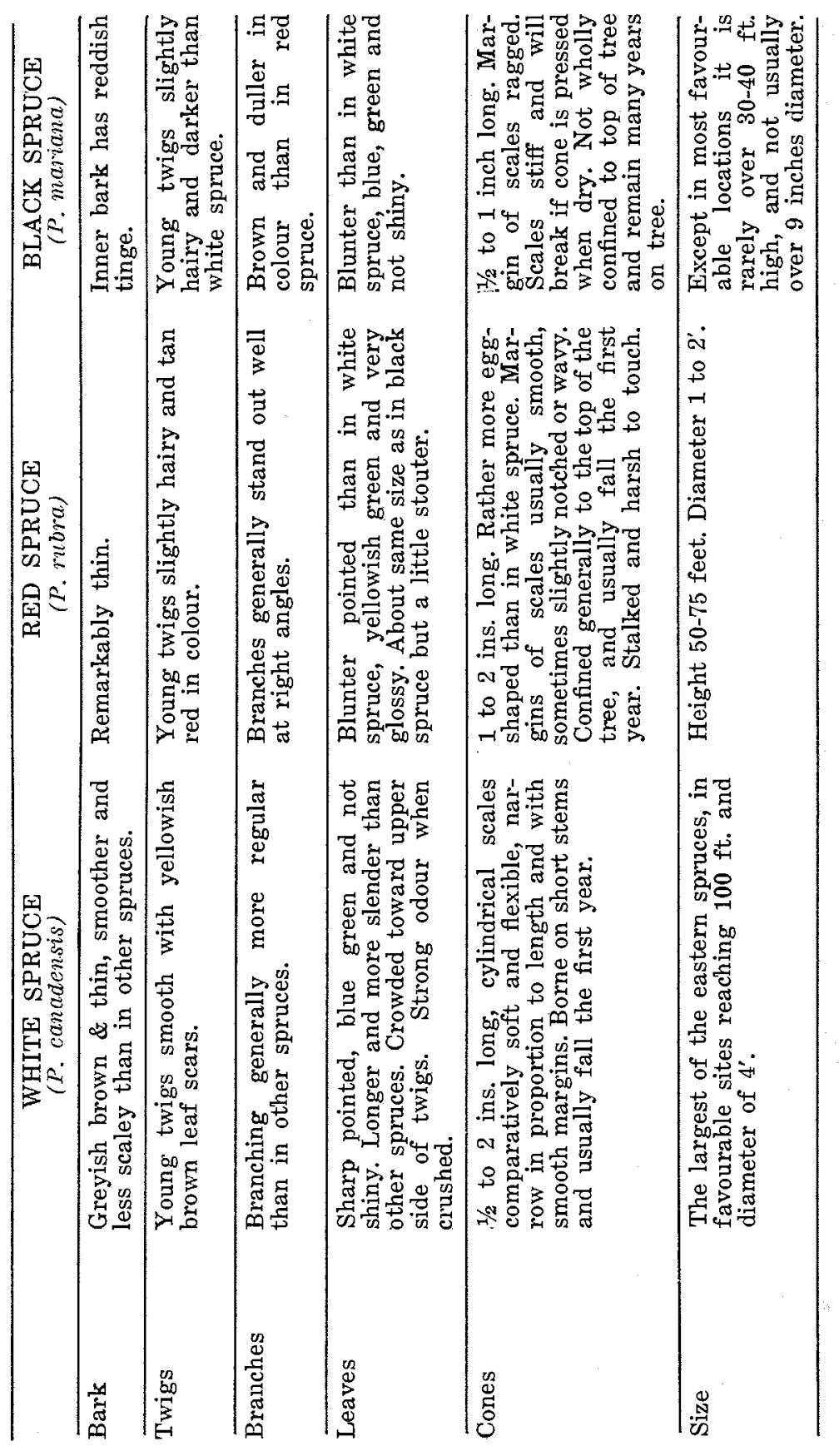


Balsam (Abies balsamea).-Leaves scattered, distinguished from spruce by being flexible, flat, with prominent mid-rib on whitened lower surface and appearing 2 ranked on the horizontal branches.

Cones borne erect on upper side of spreading branches, maturing the first year, the thin scales falling off at maturity and leaving the cone axis as a bare spike.

The bark of balsam is very smooth, greyish brown in colour and conspicuously marked by the raised blisters previously mentioned.

A tree 50 to 60 feet in height and rarely 2 feet in diameter.

Jack Pine (Pinus Banksiana). - Leaves in 2's, short, rarely more than $11 / 4$ inches long.

Cones, conical oblong, usually curved and remaining closed on the tree for long periods unless opened by very intense sunshine or the heart of a forest fire.

The bark of jack pine is thin and reddish brown in colour with a yellowish tinge toward the top of the tree.

A medium size tree sometimes reaching a diameter of $1 \frac{1}{2}$ or rarely 2 feet and a height of 70 feet.

Tamarack or Eastern Larch (Larix laricina).--Leaves needle-like, $3 / 4$ to $11 / 4$ inches long, growing in clusters on short shoots which appear as knob-like growths on twigs. Larch loses its leaves in the fall.

Cones, small, rarely exceeding $1 / 2$ inch in length.

Branches characterized by the knob-like shoots which bear the leaves.

The bark is slightly roughened by small flat scales of a reddish colour.

Tamarack reaches a height of $60-70$ feet and a diameter of 1 to 2 feet.

Hemlock (Tsuga canadensis).-Leaves usually not longer than $1 / 2$ inch. 2 ranked bright green above and silvery beneath.

Cones, ovoid, rarely over $11 / 4$ inches long.

Bark reddish brown roughened by shallow fissures and ridges.

Hemlock averages $11 / 2$ to 2 feet in diameter and 50 to 70 feet in height, although it is sometimes larger.

\section{CHARACTERS OF WOOD}

Spruce.-Wood, light coloured, heartwood and sapwood the same colour. The transition from springwood to summerwood is gradual (see figures 1 and 4 ), and the summerwood is not very conspicuous except in black spruce (Picea mariana). In freshly cut logs the sapwood, which is much wetter than the heart, is distinguishable as a wet outer band of wood. Resin exudes slightly from the cut sapwood tending to spread over the exposed sapwood areas at ends of logs, making such areas somewhat sticky to the touch until the surface has dried. Sometimes in peeled logs resin is visible in small globules or irregular patches on sides of log. White spruce has generally the 
softest wood of the eastern spruces, the summerwood being very inconspicuous. White spruce can often be distinguished by its size.

The wood of black spruce is harder, being generally slower in growth and with a greater proportion of summerwood than the other two spruces.

Red spruce is intermediate in summerwood content between the other two spruces.

Jack Pine.-Sapwood light coloured, heartwood slightly orange or reddish brown and darkening on exposure. The transition from springwood to summerwood is more abrupt than in spruce and the summerwood of jack pine is relatively prominent (see figures 4 and 6 ).

Exudations of resin from the sapwood of freshly cut ends of logs is more pronounced than in spruce, and is visible after the ends have dried.

According to the woodsmen of one company, peeled logs of jack pine can be distinguished readily from other pulpwood species because of the rounded swellings at the knots in jack pine. This character seems one that should be very useful for "snap" identification if it is found in all types of jack pine.

Balsam.-Wood light coloured, no definite distinction between heartwood and sapwood. Structure of wood tends to be uniform, with very gradual transition from the whitish springwood to the summerwood region, which is sometimes brownish in colour. The annual layers in balsam are often wider than those of spruce, although this character is not reliable. This wood, being without resin ducts, shows no resinous exudation.

Tamarack or Eastem Larch.- Heartwood a yellowish or russet brown tinge, sapwood distinct. Decided contrast between springwood and summerwood. Resin ducts small and scattered.

Hemlock.-Heartwood pale brown, no distinct line of demarcation from the lighter coloured sapwood. Considerable contrast between springwood and narrow summerwood. Wood without resin ducts.

\section{DIFFERENCES IN WOOD WHICH DISTINGUISH THE VARIOUS SPECIES COMPARED BY PAIRS}

(1) Spruce and Balsam.- Spruce contains resin ducts which may be indicated by exudations of resin.

Balsam is without resin ducts.

Balsam often has wider growth rings than spruce.

(2) Spruce and Jack Pine.-In jack pine there is decided contrast between the light coloured springwood and the darker summerwood, whereas in spruce the transition is gradual and the summerwood less pronounced.

Jack pine has pale orange or reddish brown heartwood, whereas the colour of spruce heartwood is the same as the whitish sapwood.

Both spruce and jack pine are characterized by resin ducts. The resin ducts of pine, however, are larger and more numerous than those of spruce. 
(3) Spruce and Tamarack.-Tamarack may be easily distinguished by its yellowish or russet heartwood. In spruce the heart is whitish and not distinguishable in colour from sapwood.

The contrast between springwood and summerwood is greater in tamarack than in spruce.

(4) Spruce and Hemlock.-Spruce is light in colour.

Hemlock is pale brown, the summerwood especially having a reddish tinge.

Wood of spruce is characterized by resin ducts.

Hemlock is without resin ducts.

(5).Balsam and Jack Pine.-Balsam is generally whitish in colour throughout the $\log$.

Jack pine has pale orange or reddish brown heart.

Balsam is uniformly soft, whereas the hard bands of summerwood in jack pine are rather conspicuous.

Balsam is without resin ducts.

Jack pine is characterized by abundant resin ducts.

(6) Balsam and Tamarack.-The yellowish brown or russet coloured heart of tamarack distinguishes it from the generally whitish balsam. Also the conspicuous bands of hard summerwood in tamarack set it apart from balsam.

Tamarack is characterized by resin ducts which do not occur in balsam.

(7) Balsam and Hemlock.-Balsam is whitish in colour and uniformly soft. Hemlock is pale brown with hard bands of summerwood.

(8) Jack Pine and Tamarack.-The heartwood of jack pine varies from a pale orange brown to a reddish brown, whereas the heart of tamarack is yellowish brown or russet. Also the sapwood in jackpine is generally thicker than in tamarack.

Resin ducts are much more numerous and larger in jack pine than in tamarack.

(9) Jack Pine and Hemlock. - Jack pine has wide distinct sapwood and a pale orange brown or reddish brown heart, whereas hemlock is generally a pale brown without distinct transition between heart and sap.

The transition from springwood to summerwood is more abrupt in jack pine than in hemlock.

Jack pine is characterized by resin ducts which do not occur in hemlock.

(10) Tamarack and Hemlock.-Tamarack has yellowish brown or russet heartwood distinct from the sapwood, whereas the color of hemlock is a pale brown, or reddish brown without distinct transition between heart and sap.

The transition from springwood to summerwood is more abrupt in tamarack than in hemlock. 
Tamarack is characterized by resin ducts which do not occur in hemlock.

Wood that is wet is, of course, darker in colour than dry wood, a factor of importance to pulpwood men, since it is often necessary to identify pulpwood fresh from the water or floating through sorting gaps. Slight traces of decay may alter the appearance of wet wood and seem exaggerated. The discoloration of wood by long flotation may (as previously mentioned) furnish another difficulty. There is also a character known as "compression wood" common to all softwoods, which alters their appearance and may cause difficulty in distinguishing the species. "Compression wood" is merely the occur" rence of heavy and hard wood found typically on one side of the tree. Where "compression wood" occurs the tree has the appearance of greatly accentuated summerwood in the affected region. The width of the annual layers is increased in the "compression wood" areas with the result that the affected trees often become eccentric. Because of the darker colour of such wood the Germans call it rotholz (red wood) a name often used in our literature on the subject. The illustration in figure 7 shows an extreme case exhibited by an 8 inch log of white spruce. It has been shown that compression wood may be caused by forces - especially wind action-which tend to compress the lee side of the tree where the so-called compression wood typically occurs. It is also common on the lower surface of lateral branches in softwoods, the region naturally under compressive stress. From material recently examined at the Laboratories, it seems probable that the occurrence of this eccentric growth is connected with partial blocking of the tree's channels of food supply on the convex surface of a mechanically bent trunk or limb. The food solution being temporarily checked in its course by the constricted passages on the convex surface of the bend may be utilized locally in abnormally large amounts on the concave surface where the food channels are freely passable. Compression wood is of common occurrence in softwoods where it may obscure the wood's identity unless recognized. The occurrence of this phenomenon is so common that reference to it is necessary in a discussion of softwoods.

The description of the method of wood identification used by the Forest Products Laboratories is given in the hope that it may be of use to inspectors of pulpwood. It is realized that identification with a lens requires too much time to be useful in all cases. It is plain that the flow of pulpwood on a conveyor cannot be stopped for a minute just to let the inspector determine the species of a log. However, the use of a pocket lens may be important in discovering how accurate present methods of "snap" identification of peeled logs may be. It is hoped to achieve the ideal method which will permit the "snap" identification of peeled pulpwood logs under any conditions. If such a method can be devised it must be by the aid of some accurate means which offers a positive check on all methods of rapid visual inspection. 